\title{
Alasan Masyarakat Kelurahan Sario Tumpaan Tidak Menggunakan Gigi Tiruan
}

\author{
${ }^{1}$ Hermina Pongsibidang \\ ${ }^{2}$ Vonny N S. Wowor \\ ${ }^{3}$ Aurelia Supit \\ ${ }^{1}$ Kandidat Skripsi Program Studi Kedokteran Gigi Fakultas Kedokteran \\ ${ }^{2}$ Bagian Ilmu Kesehatan Gigi Masyarakat Program Studi Kedokteran Gigi \\ Fakultas Kedokteran Universitas Sam Ratulangi Manado \\ ${ }^{3}$ Dosen Program Studi Kedokteran Gigi Fakultas Kedokteran \\ Universitas Sam Ratulangi Manado
}

\begin{abstract}
ABSTRAK
Kehilangan gigi tanpa adanya pengganti dapat menimbulkan berbagai dampak yaitu, berupa gangguan fungsi mastikasi, fonetik, estetik dan gangguan pada sendi temporomandibula serta memengaruhi keadaan gigi-geligi dan jaringan sekitar gigi yang hilang. Pembuatan gigi tiruan untuk menggantikan gigi yang hilang penting dilakukan agar dapat menghindari dampak tersebut. Namun pada kenyataannya tidak semua orang yang mengalami kehilangan gigi menggunakan gigi tiruan. Tujuan dari penelitian ini yaitu untuk mengetahui alasan masyarakat Kelurahan Sario Tumpaan yang kehilangan gigi namun tidak menggunakan gigi tiruan. Penelitian ini bersifat deskriptif dengan desain cross sectional study. Metode pengambilan sampel yang digunakan yaitu purposive sampling dengan jumlah sampel 100 orang dari jumlah populasi 2660 orang. Hasil penelitian yang diperoleh menunjukkan bahwa alasan terbanyak yang mendasari sehingga masyarakat Kelurahan Sario Tumpaan tidak menggunakan gigi tiruan yaitu alasan waktu, alasan pengetahuan dan alasan biaya yang hasilnya tidak terlalu berbeda jauh, yakni: alasan waktu dipilih oleh 67 responden (67\%), alasan pengetahuan dipilih oleh 61 responden (61\%) dan alasan biaya pembuatan gigi tiruan mahal dipilih oleh 59 responden (59\%).
\end{abstract}

Kata kunci: Kehilangan gigi, alasan masyarakat, gigi tiruan.

\section{ABSTRACT}

Losing tooth without replacement can cause several impacts, such as: disturbance of mastication, phonetic, esthetic function and temporomandibular joint; it also affects the condition of tooth and surrounding tissue around the lost tooth. Make denture to replace the lost tooth is important to prevent those impacts. However, in reality not all people who lost their tooth use denture. Purpose of this research was to know the reason of people in Sario Tumpaan who lost their tooth but didn't use denture. This research was descriptive with cross sectional study design. Sampling method was purposive sampling with total 100 samples from population of 2660 person. Research result showed that most reason people in Sario Tumpaan didn't use denture was time, knowledge, and cost which was not too different in result: time chose by 67 respondents (67\%), knowledge chose by 61 respondents (61\%), and high cost of denture chose by 59 respondents (59\%).

Keyword: Lost of tooth, people's reason, denture

\section{PENDAHULUAN}

Gigi berperan penting dalam kehidupan makhluk hidup, khususnya dalam proses pencernaan. Gigi berfungsi sebagai organ pengunyahan yang menghancurkan makanan sehingga memudahkan lambung dalam mencerna makanan. Selain itu juga, gigi berperan sebagai salah satu organ fonetik dan estetik yang memperindah penampilan seseorang.

Apabila seseorang mengalami kehilangan gigi dan tidak ada penggantinya akan menyebabkan gangguan mastikasi yaitu berkurangnya kemampuan seseorang untuk mengunyah, gangguan fonetik yaitu berkurangnya kemampuan seseorang 
untuk mengucapkan beberapa huruf dengan baik dan gangguan estetik yaitu berkurangnya rasa percaya diri seseorang sehingga mengakibatkan keterbatasan dalam melakukan aktivitas. ${ }^{1}$ Gigi yang hilang perlu digantikan dengan gigi tiruan, karena gigi tiruan bertujuan mengembalikan fungsi mastikasi, fonetik serta estetik yang hilang, baik kehilangan gigi sebagian maupun kehilangan gigi seluruhnya. $^{2}$

Kenyataannya tidak semua orang yang mengalami kehilangan gigi menggantikannya dengan gigi tiruan atau melakukan perawatan Prostodontik. Menurut hasil Riset Kesehatan Dasar 2007, prevalensi penggunaan gigi tiruan di Indonesia sebesar 4,6\% dan prevalensi penggunaan gigi tiruan di Sulawesi Utara sebesar 7,1\%. Ini tidak sebanding dengan prevalensi pencabutan di Indonesia yang sebesar 79,6\% dan di Sulawesi Utara sebesar 86,6\%. ${ }^{3}$ Data Dinas Kesehatan kota Manado tahun 2012 menunjukkan bahwa sebanyak 1187 orang memperoleh tindakan pencabutan gigi di kota Manado, sedangkan data mengenai penggunaan gigi tiruan belum ada. ${ }^{4}$

Hasil penelitian Teo'filo and Leles menyatakan bahwa, alasan yang paling sering bagi seseorang untuk tidak menggantikan giginya yang hilang yaitu terbatasnya kemampuan ekonomi. Alasan lainya karena jumlah gigi yang hilang hanya satu buah, kehilangan terjadi pada gigi belakang atau keterbatasan waktu yang ada untuk melakukan perawatan prostodontik. ${ }^{5}$

Berdasarkan survei awal yang dilakukan oleh penulis di Kelurahan Sario Tumpaan, ditemukan lebih dari 100 orang yang mengalami kehilangan gigi tidak menggunakan gigi tiruan. Sejauh ini kota Manado maupun provinsi Sulawesi Utara belum memiliki data statistik mengenai kondisi ini. Alasan-alasan inilah yang mendorong penulis untuk melakukan penelitian mengenai alasan yang melatarbelakangi masyarakat Kelurahan Sario Tumpaan sehingga tidak menggunakan gigi tiruan.

\section{METODE PENELITIAN}

Penelitian ini bersifat deskriptif dengan desain penelitian cross sectional study. Penelitian dilaksanakan di Kelurahan Sario Tumpaan pada bulan April-Oktober 2013. Populasi pada penelitian ini ialah masyarakat Kelurahan Sario Tumpaan yang berusia 20-85 tahun yang berjumlah 2660 orang. $^{6}$

Besar sampel yang ditentukan yaitu berjumlah 100 sampel dan teknik pengambilan sampel yang digunakan yaitu: purposive sampling. Pengambilan sampel berdasarkan kriteria dan karakteristik yang ditentukan oleh peneliti. ${ }^{7}$ Penelitian ini menggunakan kuesioner yang dipadukan dengan teknik wawancara. Setelah data yang diperoleh, data diolah dan dianalisis, kemudian disajikan dalam bentuk tabel dan grafik distribusi.

\section{HASIL PENELITIAN}

A. Karakteristik Responden

Karakteristik yang dimiliki responden dibedakan atas usia, jenis kelamin, tingkat pendidikan dan pekerjaan, sebagai berikut :

1. Usia

Usia responden dikelompokkan dan didistribusikan sebagai berikut:

Tabel 1. Distribusi frekuensi responden penelitian berdasarkan usia

\begin{tabular}{ccc}
\hline Usia & $\mathrm{n}$ & $\%$ \\
\hline 20-29 tahun & 11 & 11 \\
30-39 tahun & 8 & 8 \\
$40-49$ tahun & 26 & 26 \\
50-59 tahun & 29 & 29 \\
$60-69$ tahun & 16 & 16 \\
$70-79$ tahun & 7 & 7 \\
$80-85$ tahun & 3 & 3 \\
\hline Total & 100 & 100 \\
\hline
\end{tabular}

\section{Jenis kelamin}

Jenis kelamin responden didistribusikan dalam tabel 2 di bawah ini:

Tabel 2. Distribusi frekuensi responden penelitian berdasarkan jenis kelamin

\begin{tabular}{ccc}
\hline Jenis kelamin & $\mathrm{n}$ & $\%$ \\
\hline Laki-laki & 42 & 42 \\
Perempuan & 58 & 58 \\
\hline Total & 100 & 100 \\
\hline
\end{tabular}

\section{Tingkat pendidikan}

Tingkat pendidikan responden didistribusikan dalam tabel 3 berikut:

Tabel 3. Distribusi frekuensi responden penelitian berdasarkan tingkat pendidikan

\begin{tabular}{ccc}
\hline Tingkat pendidikan & $\mathrm{n}$ & $\%$ \\
\hline SD & 8 & 8 \\
SMP & 19 & 19 \\
SMA & 53 & 53 \\
Perguruan tinggi (PT) & 18 & 18 \\
Tidak sekolah & 2 & 2 \\
\hline Total & 100 & 100 \\
\hline
\end{tabular}




\section{Pekerjaan}

Pekerjaan responden didistribusikan dalam tabel 4 di bawah ini :

Tabel 4. Distribusi frekuensi responden penelitian berdasarkan pekerjaan

\begin{tabular}{ccc}
\hline Pekerjaan & $\mathrm{n}$ & $\%$ \\
\hline PNS & 4 & 4 \\
Wiraswasta & 17 & 17 \\
Swasta & 30 & 30 \\
Pensiunan & 14 & 14 \\
Nelayan & 4 & 4 \\
Buruh bangunan & 3 & 3 \\
Tidak ada pekerjaan & 28 & 28 \\
\hline Total & 100 & 100 \\
\hline
\end{tabular}

B. Hasil

Hasil penelitian tentang alasan masyarakat Kelurahan Sario Tumpaan tidak menggunakan gigi tiruan, terbagi berdasarkan alasan pengetahuan, alasan biaya, alasan waktu, alasan pelayanan kesehatan dan alasan lain, sebagai berikut :

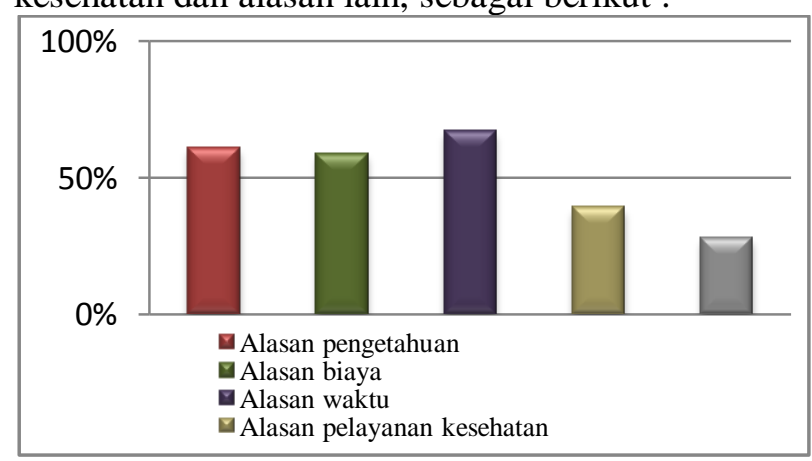

Gambar 6. Distribusi berdasarkan alasan

\section{Alasan Pengetahuan}

Hasil penelitian berdasarkan alasan pengetahuan sehingga responden tidak menggunakan gigi tiruan, dapat dilihat pada gamabar 7 di bawah ini :

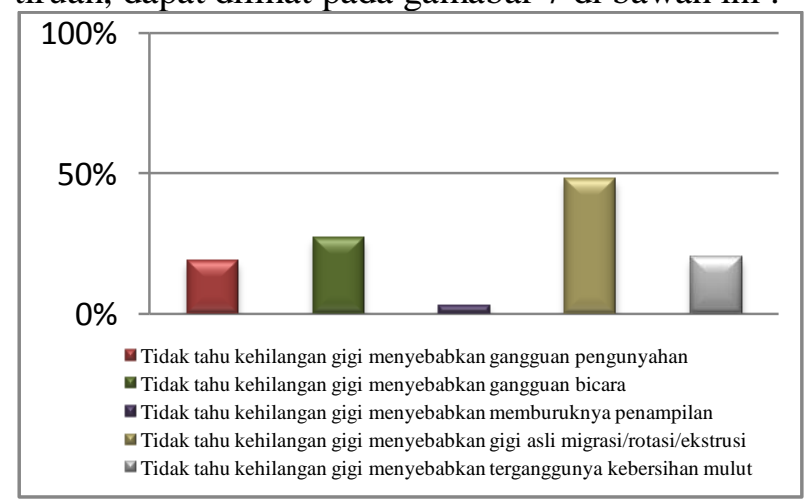

Gambar 7. Distribusi responden berdasarkan pengetahuan sebagai alasan

\section{Alasan Biaya}

Hasil penelitian yang menggambarkan biaya sebagai alasan responden sehingga tidak menggunakan gigi tiruan dapat dilihat pada gambar 8 di bawah ini:

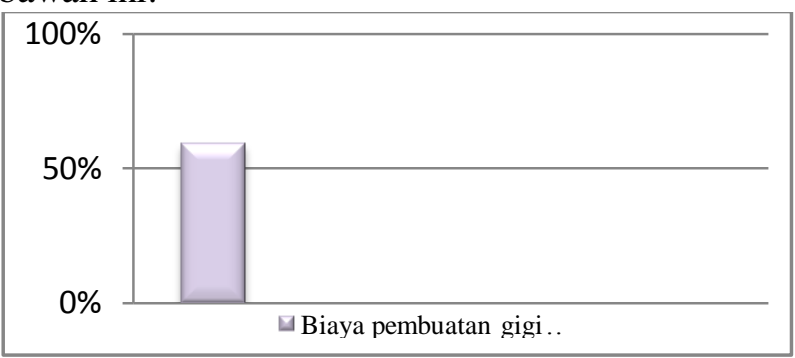

Gambar 8. Distribusi responden berdasarkan biaya sebagai alasan

\section{Alasan Waktu}

Hasil penelitian yang menggambarkan waktu sebagai alasan responden sehingga tidak menggunakan gigi tiruan dapat dilihat pada gambar 9 di bawah ini:

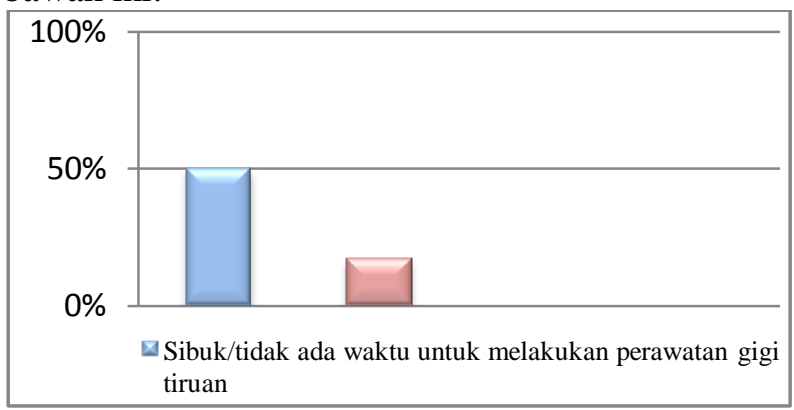

Gambar 9. Distribusi responden berdasarkan waktu sebagai alasan

\section{Alasan Pelayanan Kesehatan}

Hasil penelitian yang menggambarkan pelayanan kesehatan sebagai alasan sehingga responden tidak menggunakan gigi tiruan dapat dilihat pada gambar 10 di bawah ini :

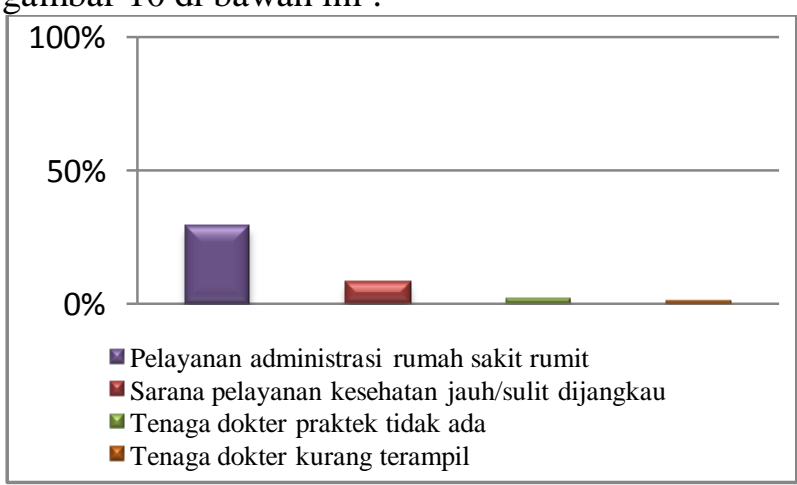

Gambar 10. Distribusi responden berdasarkan pelayanan kesehatan sebagai alasan 


\section{Alasan Lain}

Hasil penelitian yang menggambarkan alasan lainnya yang melatarbelakangi responden sehingga tidak menggunakan gigi tiruan dapat dilihat pada gambar 11 di bawah ini :

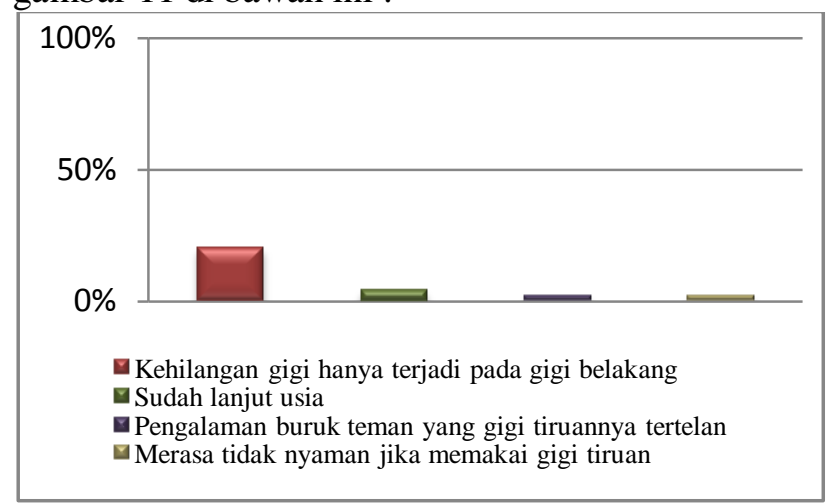

Gambar 11. Distribusi responden berdasarkan alasan lain

\section{PEMBAHASAN}

Hasil penelitian tentang alasan masyarakat Kelurahan Sario Tumpaan tidak menggunakan gigi tiruan, menunjukkan bahwa alasan yang paling banyak yang mendasari sehingga masyarakat setempat tidak menggunakan gigi tiruan yaitu alasan waktu. Dari 100 responden yang diteliti 67 responden (67\%) tidak menggunakan gigi tiruan karena alasan waktu, dimana sebanyak 50 responden $(50 \%)$ menyatakan sibuk atau tidak ada waktu untuk melakukan perawatan gigi tiruan. Menurut pendapat peneliti, hal ini dikarenakan responden yang diteliti lebih memrioritaskan pekerjaan atau kegiatan lain yang dianggap lebih penting. Pekerjaan terbanyak yang dimiliki oleh responden dalam penelitian ini yaitu swasta sebanyak 30 responden (30\%) dan wiraswasta sebanyak 17 responden (17\%). Mungkin saja pekerjaan responden yang dikategorikan sebagai pekerja swasta semisal karyawan pertokoan atau pekerja harian yang menuntut mereka untuk tidak bolos kerja, karena akan berdampak pada pemotongan atau pengurangan gajinya. Selain itu, perawatan gigi tiruan menuntut kunjungan lebih dari sekali. Hal ini menunjukkan bahwa bagi responden seperti ini perawatan gigi tiruan bukan merupakan prioritas utama. Demikian halnya dengan responden yang berprofesi sebagai wiraswasta atau wirausaha yang disibukkan dengan urusan dagangannya. Hasil penelitian yang dilakukan oleh Jubhari menunjukkan dari 30 orang yang diteliti, 12 orang di antaranya menyatakan bahwa tidak ada waktu atau belum sempat untuk melakukan perawatan gigi tiruan. ${ }^{8}$ Dari hasil penelitian yang dilakukan oleh Shigli dkk, juga menyatakan 7,1\% responden dalam penelitiannya beralasan bahwa mereka tidak memiliki waktu untuk mengganti giginya yang hilang dengan gigi tiruan. ${ }^{9}$

Selanjutnya dari 17 responden (17\%) menyatakan bahwa perawatan gigi tiruan menyita waktu. Untuk mendapatkan perawatan gigi tiruan yang ideal, pembuatan gigi tiruan membutuhkan waktu yang tidak sedikit. Perawatan gigi tiruan dibutuhkan penanganan yang bertahap sehingga tidak bisa diselesaikan dalam satu kali kunjungan ke dokter gigi atau ke rumah sakit, sebab proses pembuatan gigi tiruan tidak hanya dilakukan di klinik saja tetapi ada tahapan yang harus dikerjakan di laboratorium sehingga membutuhkan waktu yang cukup banyak.

Alasan kedua terbanyak yang merupakan alasan, sehingga responden dalam penelitian ini tidak menggunakan gigi tiruan yaitu alasan pengetahuan. Berdasarkan hasil yang ada 61 responden $(61 \%)$ memilih pengetahuan sebagai alasan yang melatarbelakangi sehingga responden tidak menggunakan gigi tiruan, dimana alasan responden berkaitan dengan pengetahuan bervariasi. Hasil penelitian menunjukkan 48 responden (48\%) tidak mengetahui bahwa kehilangan gigi menyebabkan gigi yang masih ada mengalami migrasi, rotasi atau ekstrusi dan 27 responden (27\%) tidak mengetahui bahwa kehilangan gigi menyebabkan gangguan pada fungsi bicara, serta sebanyak 20 responden (20\%) tidak tahu kehilangan gigi menyebabkan terganggunya kebersihan mulut. Meskipun demikian terdapat sebagian besar responden yang diteliti memahami akan dampak kehilangan gigi terhadap fungsi pengunyahan dan penampilan. Menurut pendapat peneliti, responden dapat memperoleh informasi serta mengetahui bahwa kehilangan gigi dapat menyebabkan gigi yang masih ada menjadi migrasi, rotasi dan ekstrusi, serta tergangguannya fungsi bicara dan terganggunya kebersihan mulut, apabila responden sering melakukan kontrol kesehatan gigi dan mulut enam bulan sekali ke dokter gigi. Dengan demikian apabila responden mengalami kehilangan gigi akan diberikan informasi oleh dokter gigi yang merawatnya tentang dampak kehilangan gigi yang tidak diganti. Selain itu, pengetahuan yang dimiliki seseorang berhubungan dengan tingkat pendidikan yang dimiliki. 
Hasil penelitian memperlihatkan bahwa pendidikan responden sebagian besar lulusan SMA ke bawah, dimana terbesar adalah lulus SMA (53\%). Notoatmodjo dalam bukunya berjudul promosi kesehatan teori dan aplikasi menyatakan bahwa pengetahuan sangat erat kaitannya dengan tingkat pendidikan dimana diharapkan seseorang dengan tingkat pendidikan tinggi yang dimilikinya, maka pengetahuannya akan semakin luas. ${ }^{10}$ Hasil penelitian yang dilakukan oleh Esan dkk, menyatakan bahwa seseorang yang memiliki status pendidikan yang lebih tinggi, lebih banyak mendapatkan informasi tentang kebutuhan kesehatan sehingga dapat mencari perawatan gigi lebih awal, dibandingkan dengan seseorang yang memiliki status pendidikan rendah yang hanya dapat mencari atau melakukan pengobatan gigi ketika ada morbiditas. ${ }^{11}$

Jika dilihat dari hasil yang ada, responden yang diteliti hampir sebagian besar memahami dampak dari kehilangan gigi terhadap fungsi pengunyahan dan penampilan, tetapi pada kenyataannya responden tidak menggunakan gigi tiruan. Penulis berasumsi hal ini dapat dikaitkan dengan status ekonomi dari responden yang berkaitan dengan tingkat pendidikan. Pernyataan ini ditunjang dengan penelitian yang dilakukan oleh Baran dkk, menyatakan bahwa adanya hubungan antara tingkat pendidikan dengan status ekonomi dalam menentukan seseorang untuk melakukan perawatan gigi tiruan. $^{12}$

Hasil penelitian dimana biaya merupakan alasan responden sehingga tidak menggunakan gigi tiruan, menunjukkan bahwa sebanyak 59 responden (59\%) beralasan biaya pembuatan gigi tiruan mahal. Hal ini memang demikian kenyataannya walaupun urusan biaya relatif. Pembuatan gigi tiruan relatif lebih mahal dibandingkan jenis perawatan lainnya, karena dalam pembuatan gigi tiruan membutuhkan teknik serta keterampilan yang spesifik, demikian juga dengan jenis bahan yang digunakan. Di samping itu tahap perawatannya meliputi tahap klinis dan tahap laboratorium, sehingga kondisi ini yang menyebabkan biaya pembuatan gigi tiruan lebih tinggi. Selain itu, hal ini dapat dihubungkan juga dengan pekerjaan yang dimiliki oleh responden. Pekerjaan terbanyak yang dimiliki oleh responden dalam penelitian ini ialah swasta sebanyak 30 responden $(30 \%)$, sedangkan yang tidak memiliki pekerjaan sebanyak 28 responden $(28 \%)$. Jika dilihat dari jenis pekerjaan responden yang ada dan dihubungkan dengan tingkat pendidikan, maka pendapatan perbulannya bisa dikatakan tidak begitu besar dan kemungkinan berkisar pada upah minimum regional (UMR). UMR di provinsi Sulawesi Utara saat ini sebesar satu juta lima ratus lima puluh ribu rupiah perbulannya. ${ }^{13}$ Dari pendapatan yang ada masih harus digunakan untuk biaya rumah tangga atau biaya keperluan lainnya yang dianggap lebih penting. Sebaliknya untuk responden yang tidak memiliki pekerjaan, secara tidak langsung akan berpikir dua kali untuk melakukan perawatan gigi tiruan, sebab untuk biaya hidup sehari-hari boleh dikatakan pas-pasan. Mungkin hal inilah sebagai pertimbangan-pertimbangan masyarakat sehingga tidak melakukan perawatan gigi tiruan.

Hasil penelitian yang diperoleh sejalan dengan yang dilakukan oleh Teo'filo dan Leles, menyatakan bahwa 88,8\% dari responden dalam penelitiannya memiliki kendala keuangan yang merupakan alasan sehingga tidak melakukan perawatan gigi tiruan. ${ }^{5}$ Ini juga sesuai dengan penelitian yang dilakukan oleh McGrath dan Bedi yang menyatakan bahwa status ekonomi merupakan penentu yang paling penting bagi seseorang dalam mengambil suatu keputusan untuk melakukan perawatan gigi tiruan. ${ }^{14}$ Hasil yang sama juga diperlihatkan pada penelitian yang dilakukan oleh Shigli dkk. Penelitian tersebut menyatakan biaya merupakan hambatan bagi seseorang untuk mendapatkan perawatan gigi tiruan. Responden dalam penelitian tersebut memberikan alasan ekonomi sehingga tidak menggantikan giginya yang hilang dengan gigi tiruan. ${ }^{9}$

Hasil penelitian dimana pelayanan kesehatan merupakan alasan responden sehingga tidak menggunakan gigi tiruan, menunjukkan bahwa 29 responden (29\%) menyatakan pelayanan administrasi di rumah sakit rumit, mungkin hal inilah yang membuat masyarakat menjadi malas berkunjung ke rumah sakit untuk melakukan perawatan gigi tiruan, meskipun adanya pelayanan jaminan kesehatan masyarakat. Ini didukung dengan pernyataan Azwar yang menyatakan, walaupun masyarakat mendapatkan tunjangan asuransi kesehatan, banyak yang tidak memanfaatkannya karena pengurusan yang cukup rumit dan layanan yang tidak memuaskan dari petugas kesehatan. ${ }^{15} 8$ responden (8\%) mengatakan sarana pelayanan kesehatan jauh atau sulit dijangkau. Mungkin responden menyatakan demikian karena rumah sakit dan puskesmas 
terdekat belum melayani perawatan gigi tiruan, sehingga untuk mendapatkan perawatan gigi tiruan masyarakat setempat harus pergi ke rumah sakit yang lainnya. Selain itu, untuk melakukan perawatan gigi tiruan di rumah sakit lain memerlukan tambahan biaya transportasi, sehingga biaya yang dikeluarkan total akan lebih banyak.

Selanjutnya responden yang diteliti menyatakan tenaga dokter tidak ada, kemungkinan responden menyatakan demikian karena puskesmas Sario belum memiliki tenaga dokter gigi, dan hanya ada perawat gigi yang bertugas di puskesmas tersebut. Selain itu, responden yang ditelitipun menyatakan bahwa tenaga dokter kurang terampil, malahan merasa kalau tukang gigi lebih terampil. Mungkin saja responden mengatakan demikian karena pembuatan gigi tiruan pada tukang gigi tidak membutuhkan waktu yang lama. Ini didukung oleh penelitian Teguh yang menyatakan bahwa masyarakat lebih memilih ke tukang gigi karena tukang gigi bekerja secara cepat sehingga pasien tidak perlu menunggu lerlalu lama. ${ }^{16}$

Adapun alasan lain yang diutarakan oleh responden sehingga tidak menggunakan gigi tiruan, yaitu 20 responden $(20 \%)$ merasa tidak perlu menggunakan gigi tiruan karena kehilangan gigi hanya terjadi pada gigi belakang saja, sebab keadaan ini tidak membuat penampilan dan kegiatan sehari-hari mereka terganggu. Padahal gigi belakang berfungsi untuk menghancurkan makanan sehingga memudahkan lambung dalam mencerna makanan. Hasil penelitian yang dilakukan Teo'filo dan Leles menyatakan bahwa dari 211 responden yang diteliti $7,6 \%$ responden menganggap tidak perlu memakai gigi tiruan karena hanya satu gigi atau hanya gigi belakangnya yang hilang. ${ }^{5}$ Responden juga menganggap gigi tiruan sudah tidak dibutuhkan lagi dikarenakan usia yang sudah lanjut. Pengalaman juga dapat memengaruhi seseorang tidak menggunakan gigi tiruan, dari responden yang diteliti ada yang merasa takut menggunakan gigi tiruan karena melihat pengalaman teman yang gigi tiruannya tertelan. Selain itu ada juga yang merasa tidak nyaman jika menggunakan gigi tiruan. Penelitian yang dilakukan oleh Juliatri menyatakan responden dalam penelitiannya ada yang merasa takut menggunakan gigi tiruan karena mendengar keluhan ketidaknyamanan menggunakan gigi tiruan dari salah satu anggota keluarga. ${ }^{17}$ Alasan-alasan inilah yang membuat masyarakat Kelurahan Sario Tumpaan tidak menggunakan gigi tiruan.

\section{KESIMPULAN}

Alasan terbanyak sehingga masyarakat Kelurahan Sario Tumpaan tidak menggunakan gigi tiruan yaitu: Alasan waktu, alasan pengetahuan dan alasan biaya. Sebaliknya, alasan terendah yakni berupa tenaga dokter kurang terampil, tenaga dokter berpraktek tidak ada, adanya pengalaman teman yang gigi tiruannya tertelan, serta alasan ketidaknyamanan.

\section{SARAN}

Diharapkan pemerintah kota Manado, terlebih khusus Dinas Kesehatan kota Manado bersama jajaran di bawahnya yakni Puskesmas Sario untuk mengupayakan program-program pelayanan di bidang kesehatan, khususnya di bidang kesehatan gigi dan mulut serta penyediaan sarana prasarana pendukung serta SDM melalui:

1. Program penyuluhan tentang pentingnya menggantikan gigi yang hilang dengan gigi tiruan.

2. Penyediaan sarana kesehatan yang melayani pembuatan gigi tiruan dengan harga terjangkau

3. Penyediaan SDM yang memiliki kompetensi dalam perawatan gigi tiruan.

\section{DAFTAR PUSTAKA}

1. Gunadi HA, Margo A, Burhan LK, Suryatenggara F, Setiabudi I. Buku ajar ilmu geligi tiruan sebagian lepasan jilid 1. Jakarta: Hipokrates; 1991. h. 30-50.

2. Chiramana $\mathrm{S}$ and Ashok K. Examination, diagnosis and treatment planning for complete denture therapy- a review. Orofacial Sciences Journal. 2010; 2(3): 29-35.

3. Riset Kesehatan Dasar. Badan penelitian dan pengembangan kesehatan departemen kesehatan, Republik Indonesia. Jakarta: Laporan Nasional; 2007. h. 130-47.

4. Dinas Kesehatan Kota Manado. Profil kesehatan kota Manado. Manado: 2012

5. Teo'filo LT, Leles CR. Patient' self-perceived impacts and prostodontic need at the time and after tooth loss. Braz Dent Journal. 2007;18(2):91-96. 
6. Data kependuduk Kelurahan Sario Tumpaan Kecamatan Sario. Manado. Tahun 2012.

7. Notoatmodjo S. Metodologi penelitian kesehatan. Jakarta: Rikena Cipta; 2010. h. 124-5.

8. Jubhari EH. Alasan mahasiswa fakultas kedokteran gigi tidak menggunakan gigi tiruan. J dentofasial. 2008;7(2):124-3.

9. Shigli K, Hebbal M, Angadi GS. Attitudes towards replacement of teeth among patients at the Institute of Dental Sciences, Belgaum, India. J Dent Educ. 2007 Nov;71(11):1467-75.

10. Notodmodjo S. Promosi kesehatan teori dan aplikasi. Jakarta : Rineka cipta; 2010. h. 43.

11. Esan TA, Olusile AO, Akeredolu PA and Esan AO. Socio-demographic factors and edentulism the Nigerian experience. BMC Oral Health. 2004 [Cited 2012 juni 14]; 4(3):16. Available from: URL: http://www.biomedcentral.com/1472-6831/4/3

12. Baran I, Ergun $G$ and Semiz M. sociodemografi and economic factors affecting the acceptance of removable denture. Eur J Dent. 2007;1(2):104-110.

13. Upah Minimum Regional. [online] 2013 [cited 2013 oktober 3]. Available from: URL: http://www.gajimu.com/main/gaji/GajiMinimum/UMP-2013

14. McGrath C, Bedi R. Severe tooth loss among UK adults - who goes for oral rehabilitation?. J oral rehabil. 2002; 29:240-244.

15. Azwar A. Pengantar administrasi kesehatan. $3^{\text {rd }}$ ed. Jakarta: Binarupa; 1996. p. 157.

16. Teguh H. Tingkat kepuasan masyarakat pulau kodingareng terhadap pelayanan kesehatan gigi dan mulut. Skripsi. Fakultas Kedonteran Gigi Universitas Hasanuddin; 2006. h. 35,43.

17. Juliatri. Pola pikir mahasiswa fakultas kedokteran gigi universitas hasanuddin angkatan 2005 terhadap penggantian gigi yang hilang. Skripsi. Fakultas Kedokteran Gigi Universitas Hasanuddin; 2006. h. 35,43. 